\title{
Tinea Infection
}

National Cancer Institute

\section{Source}

National Cancer Institute. Tinea Infection. NCI Thesaurus. Code C112181.

A skin infection caused by a fungus. 